\title{
Changing Patterns of Privatization: A Comparative Study of University and Industrial Sub - Sectors of Nigeria's Economy
}

\author{
Joel N. Nwachukwu \\ Department of Political Science and Public Administration, Babcock University, Ilishan - Remo \\ Eme, Okechukwu I. \\ Department of Public Administration and Local Government, University of Nigeria, Nsukka
}

\author{
Doi:10.5901/mjss.2015.v6n3p75
}

\begin{abstract}
This paper analyzed the emerging trend of privatization in Nigeria, comparing the emergent realities between two sub- sectorseducation and industry. Between 1985 and 1998, the wave of de-nationalization of public companies, utilities and boards did not flutter the university sector. However, from 1999 to date, university education had been opened up for private participation in educational delivery with private operators founding, funding, and operating universities in such a way that had not been witnessed before. Thus the monopoly of government as the sole provider of educational services at the tertiary level has been checked. The study which deployed a descriptive analysis relying heavily on secondary sources of data, examined the new patterns of privatizing in the educational sub - sector that is not in keeping with the government's privatization model. The study argues that this radical departure from tradition was due to the failure of the government to govern for good reasons, and that privatization is bound to precipitate new and complex social problems to the university system in particular and the entire society in general.
\end{abstract}

Keywords: Deregulation, Privatization, Private Universities, De-industrialization, Cultural Lag.

\section{Introduction}

The Concise Oxford Dictionary of politics (2002) defined privatization simply as "the transfer of public assets to the private sector, by sale or contracting out". Privatization could means any of the following: Firstly, change of ownership from public to private hands were private may encompass small shareholders whether as individuals or groups, firms operating as single proprietors or companies, associations, partnerships, etc.(Orluwene 2011). 2008).

Secondly, transfer of management from public to private initiative while ownership still remains public (Adoga

Thirdly, privatization may not occur at the enterprises level but at the level of the economy in its entirety. In this case, the government may create the enabling environment for private sector to drive the economy. This will of necessity involve a complete system of new laws, regulation, tax regimes, foreign exchange management, human resources development, equity, political cum economic stability and so on. Lastly, privatization may mean opening up or breaking a public monopoly by allowing competition with private operators (Alabi 2009). Cordelli (2013), on his part defined privatization as "the way in which a government discharges critical public responsibilities through or in tandem with private associations". The first order of privatization is called divestiture, a situation which involves change of ownership from public to private. The Nigerian state could not contemplate this type of privatization for public universities. In the second order of privatization, the state concessions a public industry for a fee or price but retains ownership. The Nigerian state applied this principle to the case of the moribund Ajaokuta Steel Complex (Momo 2011).

The problem of privatization in Nigeria as elsewhere is the leeway it offers public officials, to corruptly enrich themselves. Stiglitz (2007) identifies four basic mechanisms for diversion of public assets and resources into private use in the name of privatization:

First, reduce competition; secondly (particularly relevant in economies in transition when capital markets were not well developed), channel funds to favorities; third, provide favorities with inside information about the value of what is being sold; and fourth, enforce terms asymmetrically.

Nwachukwu (2009) notes a worst kind of corrupt privatization of public industry by government officials in Nigeria. This typology of corruption involves outright swindle in which public officials introduced "fake" investors to "fund", 
"reactivate", and "operate" a state - owned steel company for 10 years. He laments that these fake industrialists (SOLGAS American Energy Company (was merely a marketing outfit for small - scale capacity electric generators; and Global Infrastructure Nigeria Limited, Indian Company) had neither fund nor the technical know-how for running of the steel complex. As a result, the public steel sub-sector of the economy had been basterdized and abandoned.

\section{Pro-Privatization Arguments}

The National Council of Privatization (in Nigeria) argues very copiously "that privatization permits government to concentrate resources on their core functions and responsibilities, while enforcing the rule of the game" so that the market can work efficiently, with provisions of adequate security and basic infrastructure, as well as ensuring access to key services like education, health and environmental protection (see Privatization Handbook, 2000:x)

\section{Anti - Privatization Argument}

These debunk the above statement as it relate to Nigeria in view of the observable fact that privatization means weakening the power of public sector trade unions, loss of jobs, decaying infrastructure; corrupt officials who sell hitherto publicly owned industries are also the buyers. This widens the gap between the poor and the rich. Lastly, privatization in many of the developing countries automatically means de-industrialization (Nwachukwu 2009).

The concepts of de-industrialization, and cultural gap afford us the theoretic content of this analysis. Bluestone (1988:35) defined de-industrialization as "a systematic decline in the industrial base or the process whereby the proportion of jobs in the manufacturing sector of the economy decreases cover time". When de-industrialization is going on, as in Nigeria since 1999, factories, stores and government industries shut down with loss of hundreds of thousands of jobs. De-industrialization itself is attributed to the globalization imperatives. Its implication for the working class is far reaching. Giddens and Duneier (2000:323) insist that it makes for downward mobility, a common experience for bluecollar workers with serious implication for their economic and psychological welfare as well as for the wellbeing of their dependants. A lag in culture occurs when one of two sides of culture which are related changed before or in greater degree than the other part does; thereby causing little adjustment between the two aspects that existed previously (Bloom and Selznick, 1977:547). So this study holds a strong view that Nigeria economy is facing a serious maladjustment because of cultural lag i.e. a situation where the educational sector continues to increase by leaps and bounds as a result of the invention of private universities, while leaving the industrial sector behind. The latter is ailing, declining and winding down. The meaning is that today's university graduates in Nigeria have lost hope of working at all. Only few that could be self employed are exempt from this bleak future.

\section{A Heuristic Analysis of Privatization of Industry in Nigeria}

The 1973 indigenization decree which sought to place the commanding heights of Nigeria's economy in the hands of Nigerians led to the take-over of internationally controlled corporations by the state. Consequently, over 1000 state owned corporations were established. These companies which included banks, education, agriculture, steel companies, housing, power, and manufacturing, among others, operated as monopolies and were easily funded by the bourgeoning sovereign wealth from oil (Adoga, 2008). Barely 10 years after, the scenario had changed as international oil prices crashed, coupled with the fact that profits from these corporations stopped coming as a single slip corruption plummeted it.

In the face of these daunting problems, the question was whether Nigeria would revert to the status-quos by allowing a private sector driven market in order to ensure an efficient and quality service delivery with its concomitant improvement in infrastructure and the development of human capital while releasing the government from budgetary overstretch and expenditure (Adoga, 2008). Kingdom (1995) suggests three steps or modalities involved in policy change which we find to be germane to Nigeria's case when considering the change of gear from operating huge government owned monopolies that could not break - even to a political economy that is driven by market forces. These modalities are "problems", "policies", and "political processes". While the problem process deals with the issue (this time privatization) which has been able to climb up to national agenda and attracted political visibility, policy process ensures that potential solutions are provided for the problems. "Political processes" on the other hand incorporates, and operates on the same continuum with the first two factors. According to Colley and Head (2013):

It includes both stable and unpredictable elements, such as the changing national mood, diverse organized political forces, and changes in the political color of successive administrations. 
However, Fink (2011) argues that deregulation and the concomitant privatization which swept across the globe in the 1970s and 1980s came as a result of unassessed contagious mood. Privatization became, for many developed nations an attractive pill for the cure of most of the economic problems of the period. But for the developing countries, it was prescribed by the multilateral institutions as a panacea to the problems of underdevelopment and poverty.

\section{Institutional Framework for Privatization}

By 1988, the Federal Military Government was already wearing the wood by embracing the neo-liberal approach that questioned the growing role of government, by privatizing some key industries. The first step taken by the government was to set up a Technical Committee on Privatization of Public Companies (TCPC). Its terms of reference were to sale off government equities in the Nigerian capital market, privatize commercial and merchant banks, steel companies, cement companies etc. Adoga (2012) averred:

The consequences were drastic as they were successful. The immediate impact was the expansion of the Nigerian economy buoyed by private sector involvement. Public services improved in the designated corporations as well as their financial bases by the injection of private sector capital.

To consolidate on this achievement the government went a step further and created the Bureau for Public Enterprises (BPE) in 1999. The National Council on Privatization (NCP) was also established to oversee the functions of (BPE). These regulatory bodies had to take over from the TCPC having come into existence by the promulgation of Public Enterprises (Privatization and Commercialization) Decree 1999 (Orluwene 2011).

\section{Policy Process}

The policy process on privatization in 1999 was set rolling by a policy statement made by President Olusegun Obasanjo on the occasion of the inauguration of the National Council on Privatization in July 1999, thus:

Up till recently, there had been many years of exhaustive deliberations by stakeholders on how to put the Nigerian economy on the path of sustainable growth and development. Right now, a consensus has emerged on the imperative of privatization and commercialization of state-owned enterprises.

Consequently, the BPE was assigned the statutory functions and activities leading to the privatization and commercialization of state industries. Some of these function which are listed in the privatization Handbook (2005:5-13) include among others:

a. Implement the Council's policy on privatization

b. Prepare public enterprises approved by the Council for privatization

c. Advise the Council on further public enterprises that may be privatized

d. Advise the Council on the capital restructuring needs of the public enterprises to be privatized.

To fast track the work of the "Bureau", all state-owned enterprises were identified and arranged into sectoral groups indicating the name of the enterprises, structure of the shareholding, privatization policy outline, time schedules etc as shown on table 1.5 below

Table 1.5: Some of the enterprises scheduled for full or partial privatization as envisaged by the public enterprises (Privatization and Commercialization) Act No.28 of 1999.

\begin{tabular}{|c|c|c|c|}
\hline \multicolumn{4}{|c|}{ Aviation } \\
\hline No. & $\begin{array}{l}\text { PARASTATALS } \\
\end{array}$ & ENABLING DECREE & PRIVATISATION/COMMERCIALIZATION \\
\hline 1. & Federal Airport Authority of Nigeria & Decree 9 of 1996 & Privatisation \\
\hline 2. & Nigeria Airways Limited & Limited Liability & Privatisation \\
\hline \multicolumn{4}{|c|}{ Communication } \\
\hline No. & PARASTATALS & ENABLING DECREE & PRIVATISATION/COMMERCIALIZATION \\
\hline 3. & Nigerian Telecommunications Limited & Limited Liability & Privatisation \\
\hline 4. & Nigerian Mobile Telecommunications Ltd & Limited Liability & Privatisation \\
\hline 5. & Nigerian Postal Service & Decree 41 of 1992 & Commercialisation \\
\hline \multicolumn{4}{|c|}{ Defence } \\
\hline No. & PARASTATALS & ENABLING DECREE & PRIVATISATION/COMMERCIALIZATION \\
\hline 6. & Tafawa Balewa Square Investments Ltd & Limited Liability & Commercialisation \\
\hline
\end{tabular}




\begin{tabular}{|c|l|c|c|}
\hline No. & PARASTATALS & FNAnance \\
\hline 7. & Nicon Insurance Ltd. & LFN Cap 263 & PRIVATISATION/COMMERCIALIZATION \\
\hline 8. & Nigeria Reinsurance Company Ltd. & LFN Cap 325 & Privatisation \\
\hline 9. & Nigerian Bank for commerce \& Industry & LFN Cap 296 & Privatisation \\
\hline 10. & Assurance Bank Ltd. (former Arab Bank) & Limited Liability & Commercialisation \\
\hline 11. & FSB Int. Bank PIc (NNPC/NMA/ etc shares) & Limited Liability & Privatisation \\
\hline 12. & Afribank Nigeria Ltd (BIAO Shares) & Limited Liability & Privatisation \\
\hline
\end{tabular}

Information and Culture
\begin{tabular}{|c|l|c|c|}
\hline No. & PARASTATALS & ENABLING DECREE & PRIVATISATION/COMMERCIALIZATION \\
\hline 13. & Daily Times of Nigeria Plc & NICON Acquisition & Privatisation \\
\hline 14. & Federal Radio Corporation of Nigeria & Decree 8 of 1978 & Privatisation \\
\hline 15. & New Nigerian Newspapers Limited & & Privatisation \\
\hline 16. & News Agency of Nigeria & Decree 19 of 1976 & Commercialisation \\
\hline 17. & Nigerian Television Authority & Decree 24 of 1977 & Commercialisation \\
\hline
\end{tabular}

\begin{tabular}{|c|l|c|c|}
\hline No. & PARASTATALS & ENABLING DECREE & PRIVATISATION/COMMERCIALIZATION \\
\hline 18. & National Fertilize3r Company of Nigeria & Limited Liability & Privatisation \\
\hline 19. & Federal Super-sphosphate Fertilizer Co. Ltd & Limited Liability & Privatisation \\
\hline 20. & Nigeria Machine Tools Co., Ltd & Limited Liability & Privatisation \\
\hline 21. & Nigeria National Paper & Limited Liability & Privatisation \\
\hline 22. & Nigerian Newsprint Manufacturing Co. & Limited Liability & Privatisation \\
\hline 23. & Nigeria Sugar Company Ltd, Bacita & Limited Liability & Privatisation \\
\hline 24. & Sunti Sugar Company Ltd & Limited Liability & Privatisation \\
\hline 25. & Lafiaji Sugar Company Ltd & Limited Liability & Privatisation \\
\hline 26. & Ashaka Cement Plc. & Limited Liability & Privatisation \\
\hline 27. & Benue Cement Plc & Limited Liability & Privatisation \\
\hline 28. & Cement Company of Northern Nigeria plc & Limited Liability & Privatisation \\
\hline 29. & Nigerian Cement Company Ltd., Nkalagu & Limited Liability & Privatisation \\
\hline 30. & Calabar Cement Company & Limited Liability & Privatisation \\
\hline 31. & Anambra Motor Manufacturing Co. Ltd & Limited Liability & Privatisation \\
\hline 32. & Leyland Nigeria Ltd & Limited Liability & Privatisation \\
\hline 33. & Nigerian Truck Manufacturing Co. Ltd & Limited Liability & Privatisation \\
\hline 34. & Peugeot Automobile of Nigeria Ltd & Limited Liability & Privatisation \\
\hline 35. & Volkswagen of Nigeria Ltd & Limited Liability & Privatisation \\
\hline 36. & Steyr Nigeria Ltd & Limited Liability & Privatisation \\
\hline 37. & Nigeria Romania Wood Industries Ltd. & Limited Liability & Privatisation \\
\hline 38. & West African Portland Cement Plc & Limited Liability & \\
\hline
\end{tabular}

Petroleum Resources
\begin{tabular}{|c|l|c|c|}
\hline N0. & PARASTATALS & ENABLING DECREE & PRIVATISATION/COMMERCIALISATION \\
\hline 39. & Nigerian National Petroleum Corporation & Decree 33 of 1977 & Commercialisation \\
\hline 40. & Port Harcourt Refinery \& Petrochemicals Ltd & Limited Liability & Privatisation \\
\hline 41. & Warri Refinery and Petrochemical Ltd. & Limited Liability & Privatisation \\
\hline 42. & Kaduna Refinery \& Petrochemicals Ltd. & Limited Liability & Privatisation \\
\hline 43. & Eleme Petrochemicals & Limited Liability & Privatisation \\
\hline 44. & Nigeria Petroleum Development Co. Ltd. & Limited Liability & Privatisation \\
\hline 45. & Nigerian Gas Company Ltd. & Limited Liability & Privatisation \\
\hline 46. & Pipeline Products Marketing Company Ltd. & Limited Liability & Privatisation \\
\hline 47. & African Petroleum PIc & Limited Liability & Privatisation \\
\hline 48. & UnipetrolPlc & Limited Liability & Privatisation \\
\hline 49. & National Oil \& Chemical Marketing Plc & Limited Liability & Privatisation \\
\hline 50 & Dresser Nigeria Ltd & Limited Liability & Privatisation \\
\hline 51. & Solus School Nigeria Ltd & Limited Liability & Privatisation \\
\hline 52. & A.C.M Nigeria Ltd & Limited Liability & Privatisation \\
\hline
\end{tabular}




\begin{tabular}{|c|l|l|l|}
\hline 53. & Baker Nigeria Ltd & Limited Liability & Privatisation \\
\hline 54. & SedcoForex Nigeria Ltd & Limited Liability & Privatisation \\
\hline 55. & Flopetrol Nigeria Ltd & Limited Liability & Privatisation \\
\hline 56. & Schlumberger Wise Line Co. & Limited Liability & Privatisation \\
\hline 57. & Dowell Schlumberger Nig Ltd & Limited Liability & Privatisation \\
\hline 58. & Key Drill Nigeri Ltd & Limited Liability & Privatisation \\
\hline 59. & Baroid Nigeria Ltd & Limited Liability & Privatisation \\
\hline 60. & D.C.P Ltd & Limited Liability & Privatisation \\
\hline
\end{tabular}

Power and Steel
\begin{tabular}{|c|l|c|c|}
\hline NO. & PARASTATALS & ENABLING DECREE & PRIVATISATION/COMMERCIALISATION \\
\hline 61. & Steel Rolling Mill, Oshogbo & Decree 60 of 1979 & Privatisation \\
\hline 62. & Steel Rolling Mill, Jos & Decree 60 of 1979 & Privatisation \\
\hline 63. & Steel Rolling Mill, Katsina & Decree 60 of 1979 & Privatisation \\
\hline 64. & Delta Steel Company Ltd & Limited Liability & Privatisation \\
\hline 65. & Ajaokuta Steel Company Ltd & Limited Liability & Privatisation \\
\hline 66. & Aluminum Smelter Company Ltd. & Limited Liability & Privatisation \\
\hline 67. & National Iron Ore Mining Company Limited & Decree 60 of 1979 & Privatisation \\
\hline 68. & National Electric Power Authority & LFN Cap 256 & Privatisation \\
\hline
\end{tabular}

Solid Minerals

\begin{tabular}{|c|l|c|c|}
\hline NO. & PARASTATALS & ENABLING DEGREE & PRIVATISATION/COMMERCIALISATION \\
\hline 69. & Nigerian Mining Corporation & Decree 39 of 1972 & Privatisation \\
\hline 70. & Nigerian Coal Corporation & LFN Cap 299 & Privatisation \\
\hline 71. & Nigerian Uranium Mining Co., Ltd & Limited Liability & Privatisation \\
\hline
\end{tabular}

\begin{tabular}{|c|c|c|c|}
\hline \multicolumn{3}{|c|}{ Transport } \\
\hline NO. & PARASTATALS & ENABLING DECREE & PRIVATISATION/COMMERCIALISATION \\
\hline 72. & Nigerian Ports Authority & LFN Cap 361 & Commercialisation \\
\hline 73. & Nigerian Railway Corporation & LFN Cap 323 & Commercialisation \\
\hline 74. & Nigerdoc Ltd & Limited Liability & Privatisation \\
\hline 75. & NAHCO & Limited Liability & Privatisation \\
\hline
\end{tabular}

Source: Federal government of Nigeria Privatization Handbook (2000)

\section{Reasons for Deregulation of University Education in Nigeria}

A cursory look at the table above shows that no university was listed for full privatization, partial privatization, full commercialization or partial commercialization. Between 1988 and 1999 when government came up with the idea of deregulating the economy, there were 26 federal universities, and 12 state-owned universities making a total of 38 ivory towers that had been excluded from the traditional pathway to privatization in Nigeria. The central and important questions are (1) why were the existing universities not get fully or partially privatized given the appalling conditions under which they operate? For example the federal government committee on Needs Assessment of Nigerian Public Universities (CNANPU, 2012) found that "physical facilities for teaching and learning in Nigerian universities are inadequate, dilapidated, overstretched/over-crowded, improvised. (2) Why was privatization of university education patterned differently?

To the above questions, we opine strongly that government failed to govern in this matter due to the possible consequences and reactions from the stakeholders in higher education - Academic Staff Union of Universities (ASUU), Students, Parents and critical citizens - which would have been prompt and convulsive, had the university been treated like ordinary industry. Needless to emphasize that higher education at tertiary level plays the vital role of cultural transmission, social integration, selection and allocation, personal development, as well as gate-keeping (Broom and Selznick 2004). Oyobode (2007) also described the role of education as the "acquisition, conservation and transmission of knowledge and its application to the affairs of men. So, as the entire intellectual and professional life of Nigeria depends on sound university education that provides high quality human capital, it was sensible to treat government companies, boards, and parastatals and the university system as polar opposites. Therefore, when we talk of privatization 
of university education in Nigeria, it did not come as the transfer of existing public universities to private sector, by sale or by contracting (although the feeding of students in virtually all the public universities in Nigeria has been contracted out); Nor did it come in the form of change of ownership from public to private hands or transfer of management from public to private initiative while ownership remains public. Rather, privatization of university education in Nigeria occurred at the level of the economy in its entirety. In this case, the government created the enabling legal environment by opening up or breaking a public monopoly of educational delivery by allowing competition with private operators. As of today Nigeria has over 50 private universities founded, funded, and operated by faith - based organizations, individuals, and partnerships.

Radical policy bandits in Nigeria insist that university education was privatized for the following reasons, among others. Firstly, the changing ideology of government over educational delivery which has been informed by the actions of multilateral agencies which redefined education as private rather than public good led to the privatization of universities.

Secondly private operators were brought into educational sector in order to relegate the public university system that has been 'troubling' the government by way of insisting on improved university education budget.

Thirdly the coming into existence of private universities is intended to solve the 'problem' of Academic Staff Union of Universities (ASUU) that has the penchant to twist the hand of government (through strikes, shut-downs, and energy sapping haggling) for improvement in the overall conditions of the public universities.

Fourthly, private university ownership in Nigeria is a big business with profit motive. According to Kalama et al (2011), "the privatization of education that took place between 1980 and 1990 through the granting of private licenses to individuals was done indiscriminately without proper supervision and monitoring... the beneficiaries of the privatization exercise are either serving or retired senior public office holders".

Lastly, Erinosho (2007) dubbed the floodgate of private universities that now outstrip both the federal and state universities put together in less than 15 years, "the grand conspiracy against public universities".

The argument is that 74 public universities in Nigeria with a total enrollment of only 1,259,913 undergraduate and postgraduate students, respectively, could have been empowered in terms of physical infrastructure, learning resources, and financial resources, to expand rather than establishing private universities answering to market logic.

\section{Challenges of Private Universities in Nigeria}

Public universities in Nigeria had their heyday when they enjoyed international stature and had global recognition a few decades back (Balogun, 2012). But the private universities never had a respite before they plunged into the same or worse kinds of problems faced by the public ones. The other challenges facing the private universities as identified by Olanrewaju (2012) include inadequate finance, a mismatch between growth and facilities, brain drain as well as management problem. Commenting on administration problem, Olanrewaju (2012) avers that:

All over the world universities are expected to be traditional-based institutions where democratic culture and practice are established and maintained not only through orderly leadership succession at various levels but through the upholding of the democratic virtues and pursuit of truth. Today, in some of our private universities, not only have we witnessed half-backed academia being promoted beyond their competency level through the orchestrated affirmative action (in favour of gender, religion, accident of birth place, etc), such officers have also been saddled with responsibility for which they were ill - equipped or inexperienced.

Okigbo (1992) buttresses the above idea when he stated that:

When a semi-illiterate but successful trader is appointed to the council of a university to oversee the work of outstanding scholars, it is an open denigration of the intellectual. A donkey may win prices every year for twenty years for being the best load carrier, you do not on that account, promote it to a horse.

Adeogun, Subair and Osifila (2009) indicate another dimension of challenges of private universities in terms of "excessive" and "exorbitant" school fees charged by these profit seeking private institutions. Some of them charge between N700,000 and N3million per session in tuition and boarding depending on the course offering. Although they acknowledge the fact that a modern and qualitative educational delivery must of necessity involve modern, update, and costly resources (human and material), this alone should not make access to these institutions an exclusive preserve for the children of the rich since this is bound to exacerbate the existing inequality and elitism in both university system and the society in its entirety. As they observed, the inequalities that would be created as a direct result of deregulation of educational sub-sector is against the letter and the spirit of the National Policy on Education (Federal Republic of Nigeria 2007), which insist on "the provision of equal access to educational opportunities for all citizens of the country at the primary, secondary, and tertiary levels". Another problem area for the private Universities, the government, and its 
agencies as well as the entire society, is the rate at which illegal private Universities germinate, and the inability of the licensed ones to distinguish between "charter" or government approval to establish and run a University and accreditation of programmes. Kalama, Etebu, Martha and John (2011) assert that accretion of private Universities (both legal and illegal) makes it difficult if not impossible for the Government regulatory agencies to maintain control and ensure compliance. Citing of the case of Lead City University, which according to National Universities Commission (NUC), had no accreditation for law, Nursing and post-graduate programmes but which went ahead and commenced these programmes in 2010, the authors averred that such unfortunate development was in a bad taste, to say the least, for the nascent educational sub-sector. Private Universities suffers from chronic paucity of academic staff; they are also excluded from access to grants, among other problems.

\section{Conclusion and Recommendation}

It is a well known fact that tertiary education is responsible for the production of leaders in all facets of national life: government, business, invention and innovation. But doing the same thing and expecting a different result, is unfortunate. The problems of public educational sector started with the advent of military misadventure in politics and governance in Nigeria beginning from 1967. From their actions, the successive Governments from that time showed that education was no longer the priority. Privatization which was bequeathed to Nigeria by the globalization imperative cannot solve our educational Problems. If it could, Privatization of the Universities would have followed the path trodden by industries, shops, land, banks, National insurance companies etc. Under 15 years of operation, the vulnerabilities of the private Universities are emerging to the extent that it feared that many of them might not survive these challenges to fulfill their vision and mission. Even the best among them cannot perform the feat of the old ones. This study therefore prognosticates that in no distant future, vast majority of these private Universities will suffer atrophy or merge or at best be taken over by the government.

The National Delegate Conference (NDC) of Academic staff Union of Universities (ASUU) which is the most competent when it comes to assessing the state of Education in Nigeria today, rose from its $17^{\text {th }}$ bi-annual National Conference with a communiqué part of which reads that "Education SYSTEM as it exists and functions in Nigeria, cannot be the basis of the survival and progress of Nigeria and her peoples in the $21^{\text {st }}$ century". The committee set up by the Federal Government in November 2012 to assess the needs of Nigerian public Universities, corroborate the NDC's when in one of its findings is stated that "no cutting edge research equipment/facilities" abound in our universities.

The meaning of the above is that the University system in Nigeria is operating in a squalid condition, and as such, it cannot fulfill the vision and aspirations of the people of Nigeria. Privatization is no solution to the complex problems facing higher education in Nigeria. Private Universities had only succeeded in marginally increasing the number of intakes. This paper therefore recommends that:

> The Federal Government should stop building more Universities. The last 10 Federal Universities that were established in 2012 are finding it difficult to take-off.

$>$ The myriad applications for licensing more Private universities should be dumped in the waste paper basket.

$>$ The University system in Nigeria should shut down officially for six months. This will enable the stake holdersASUU, Government, Parents, Students, and Civil Society Organizations- to convoke education conference. The conference would utilize the first three months for considering the issues that have become contingent on nursery, primary, secondary, and adult education in Nigeria. Education at this level has run riot witness the level of mass failure at primary and secondary school levels over the years that have a spill-over effect on the tertiary level. The last three months should be utilized in considering the educational cul-de-sac at the tertiary level.

$>$ This conference will determine the trajectory of future education that is not dependent, but one that can transform Nigeria to an economically viable, technologically strong, and politically stable country where peace, equity, justice, and employment are available to the vast majority of Nigerians who seek these values.

$>$ Privatized solution to the problem of education may not work out in Nigeria which has a different National history and experience from that of U.S.A. where private Universities are calling the shot. Head or tail, "modern capitalism is, by and large, based on a simple calculus: Each individual is concerned with how much he can get for himself" (Stiglitz 2007:28). This explains why one entrepreneur in Nigeria has built three private Universities located in different parts of the country. Could this be philanthropy? 


\section{References}

Adedeji, S.O and Bamidele, R.O (2002) "Economic Impact of Tertiary Education on Human Capital Development in Nigeria" in the Nigerian Economic Society: Selection Papers for the 2002 Annual conferences pp499-550.

Adeogun, A.A., Subair, S.T. and Osifila, G.I. (2009) "Deregulation of University Education in Nigeria: Problems and Prospects". Florida Journal of Educational Administration \& Policy Vol.3, Issue 1 pp 1-8.

Adoga, O. (2005) "A Critical Appraisal of Privatization in Nigeria" www.hg.org/article.asp? Retrieved 01/15/2014

Alabi, J.O (1999) "Privatization of the Nigerian Economy for the Challenges of the 21st Centsury" Text of Public Lecture delivered at the Nigerian Institute of Management, Kogi State Branch, $2^{\text {nd }}$ Quarter Public Lecture held on June $30^{\text {th }}$.

Broom, L. and Selznick, P (1977) Sociology: A Text with Adapted Readings (3rd Ed.) New York: Harper and Row Publishers

Colley, L.K and Head, B. (2013) "Changing Patterns of Privatization: Ideology, Economic Necessity, or Political Opportunism". International Journal of Public Administration, 36:865-875.

Cordelli, C. (2013) "How Privatization Threatens the Private". Critical Review of International Social and Political Philosophy Vol.16 number 1pp65-87.

Erinosho, L (2007) "The Grand Conspiracy Against Public Universities, in the National Scholar, A Publication of Academic Staff Union of Universities Vol.5. No.7

Fink, S. (2011) "A Contagious Concept: Explaining the Spread of Privatization in the Telecommunications Sector. Governance: An International Journal of Policy, Administration, and Institutions, 24 (1) 111-139.

Giddens, A. and Duneier (2002) Introduction to Sociology (3rd Ed.) London: www.Norton and Company Ltd.

Jacques, D. (1998) "Global campaign to Defense and Enhance Public Education". International Meeting in Washington DC

Kalama, J., Etebu, C.E., Charlse, A.M and Sophia, M.J. (2011) "Impact of Unregulated Privatization of Education in Nigeria: Appraisal of the Lead City University - National Universities Commission Dispute". Mediterranean Journal of Social Sciences. Vol. 2(7), Pp 117-121.

Kingdom, J. (1995) Agendas, Alternatives and Public Policies (2nd Ed.) New York: Harper Collins.

Momoh, A. (2011) "Privatization Commercialization Programmes: Response of Government and Labour". A Papper Presented at PENGASSAN National Workshop, Abuja December 13/14

Federal Republic of Nigeria (2000) National Council on Privatization, Privatization Handbook. (2 ${ }^{\text {nd }}$ edition) Ibadan: Spectrum Books Limited.

Nwachukwu, J.N (2009) "De-Industrialization via Privatization Exercise in Nigeria: The Case of Ajaokuta Steel Company Ltd. (ASCL) Babcock Journal of Management and Social Sciences Volume 7. Number 1\&2, August.

Olusegun Obasanjo (1999) "The Imperative of Privatization". A Policy Statement by Nigeria's Former Head of State, on the Occasion of the Inauguration of the National Council on Privatization at Presidential Villa, Abuja on July 29.

Orluwene, O.B (2011) "Privatization and Commercialization Policy in Nigeria" in Lambert C, Nwachukwu, Obinna Onwubiko and Anthony E. Obi (eds) Readings on the Nigerian Public Service. Onitsha: Book Point Educational Ltd.

Osagie, A.U. (2009) Change and Choice: The Development of Private Universities in Nigeria Benin City: Rawel Fortune Resources.

Oyebode, A. (2007) "Autobiographical Step to Better Nigerian Universities". The Guardian June 18.

Stiglitz, J.E. (2007) "What is the Role of the State?" in Macartan Heimphalys, Jeffrey D. Sachas Joseph E. Stiglitz (eds) Escaping the Resource Course. Columbia University Press. 